\title{
DIRECT XPS ANALYSIS OF BIOLOGICAL MATERIALS FOR ENVIRONMENTAL PURPOSES
}

\author{
GARCÍA-BEDOYA, D. ${ }^{* 1}$ - RAMÍREZ-RODRÍGUEZ, L. P. ${ }^{2,3}$ - MENDIVIL-REYNOSO, T. ${ }^{3}$ - QUIROZ- \\ CAStillo, J. M. ${ }^{1}-$ De La Mora-Covarrubias, A. ${ }^{4}-$ CASTILlo, S. J. $^{2}$ \\ ${ }^{1}$ P.E. Ingeniería Ambiental, Universidad Estatal de Sonora, Ley Federal del Trabajo e Israel \\ González S/N, C.P. 83100, Hermosillo, Sonora, México
}

${ }^{2}$ Departamento de Investigación en Física, Universidad de Sonora, Rosales y Luis Encinas S/N, Apdo. Postal 5-088, C.P. 83000, Hermosillo, Sonora, México

${ }^{3}$ Departamento de Física, Universidad de Sonora, Rosales y Luis Encinas S/N, C.P. 83000, Hermosillo, Sonora, México

${ }^{4}$ Universidad Autónoma de Ciudad Juárez. Cd. Juárez, Chihuahua, México

*Corresponding author

e-mail: dgbedoya@gmail.com; tel: +52-166-2282-4860

(Received $10^{\text {th }}$ Jun 2016; accepted $12^{\text {th }}$ Sep 2016)

\begin{abstract}
Fish tissues were analyzed directly with an X-ray photoelectron spectroscopy (XPS) system in order to find pollutant elements that may be bioaccumulated in the fish's body in a river that is in contact with the mining industry. XPS method could be used as a first technique to find a wide gamma of elements before using conventional methods. Fish tissue was homogenized in order to make it able to be analyzed by a surface analysis, Whole fishes were analyzed by two homogenizing methods: incineration at $350^{\circ} \mathrm{C}$, and by dehydration and crushing in a ball mill. Both methods tested show different results in the same samples. It has been observed that in the incinerated samples the bonding energy is more intense, this could be a result of the elements' oxidation due to the combustion. Other difference is that in the incinerated samples there are some elements that are not shown in the dehydrated samples. Because of this, we suggest that the incineration should be the adequate technique to continue analyzing this kind of materials.
\end{abstract}

Keywords: X-ray photoelectron spectroscopy (XPS); environmental monitoring; pollution detection techniques; fish tissues; environmental chemistry

\section{Introduction}

The junction of specialized cells is defined as a tissue (Walpole et al., 2011). Tissues are capable of encapsulate elements or substances that may be hazardous to an entire organism; this process is called bioaccumulation (Oost et al., 2003). Some techniques are used to identify the elements accumulated in a tissue and these are capable to determine even the concentrations (Han and Weber, 1988). The most popular technique is the called atomic absorption spectroscopy (AAS), this has been certified for legal purposes when detecting contamination in different matrices (water, soil, air, among others) (NOM-001-ECOL-1996). Although it is a universal and precise technique, it has some flaws, especially when it's about organic materials (tissues), maybe the most remarkable flaw is the amount of material and its sample destructiveness (Mugica et al., 2003). These problems come with some factors to be considered: the sample must be vast, it can only be measured once, and it becomes a bigger issue when it's about a protected specie tissue's sample (Carvalho et al., 2005). In this paper, we proposed as an alternative methodology the X ray photoelectron spectroscopy (XPS) that could work 
with a minimum amount of material that will not be destructed in the analysis. XPS is a surface analysis method used commonly in biology to measure the chemical composition of bacteria colonies (Rouxhet and Genet, 1991). This is because the colonies' formations are very thin and the organisms are composed just by one kind of tissue (Bundle, 1992). With bigger organisms, XPS has not been used due to its limitation as a surface technique (about only eight microns in deep); this is because elements stored in a tissue, might be in any part of it, not just on the surface. In the present work, fish tissues have been analyzed by two different methodologies to achieve a homogeneous material that could be representative of the whole animal (McArthur, 2006). We hope that these procedures help to obtain ecotoxicology information with less organisms' samples and samples that could be stored and compared in future broader and complex studies.

\section{Methodology}

The study was conducted in a river that has influence by miner activity. The river "Moctezuma", is located in the Nacozari, Cumpas and Moctezuma municipalities in Sonora, Mexico. Twelve sampling stations were worked along the river from the upper river, in theory less contaminated area, to San Pedro's dam, where all contaminants may be retained as a lower basin's reservoir (Taylor, 2008).

Fish were collected by using plastic minow traps, traps were settled facing upstream by 24 hours in order to catch fishes with diurnal and nocturnal habits, the deepth was about $40 \mathrm{~cm}$ and vegetation was always present in order to have primary consumers and predators (Esacalera-Vazquez and Zambrano, 2010). Once captured, fish were classified for further analysis, and prepared in order to obtain a homogeneous material that could be sample representative, and measured by a surface analysis method where the materials depth was no relevant (Maurice-Bourgoin et al., 2000). We must mention that this paper is about the elements presents in the fishes tissues rather than the fish ecology, but we can mention the species we found and where XPS analysis were performed (Table 1) and due to the amount of indivudual we decide to perform XPS analysis with Poeciliopsis occidentalis (Baird and Girard, 1853).

Table 1. Fish species collected in this study

\begin{tabular}{lc}
\hline \multicolumn{1}{c}{ Specie } & $\begin{array}{c}\text { Number of } \\
\text { specimens }\end{array}$ \\
\hline Poeciliopsis occidentalis & 355 \\
\hline Catostomus bernardini & 11 \\
Rhinichthys osculus & 1 \\
Campostoma ornatum & 166 \\
Gila intermedia & 28 \\
Agosia chrysogaster & 33 \\
\hline
\end{tabular}

To achieve XPS analysis, we prepared the fish by two different procedures. The first one consisted in burning the whole fish to ashes $\left(350^{\circ} \mathrm{C}\right)$ and homogenized with a mortar until we got a smooth dust. Second, fish were dried in a crystal dryer' with silica gel and then homogenized with a spheres' mill. We must emphasize that this 
might be the first approach to analize organic matter from a complex animal by XPS technique due to the X-ray impossibility to travel out a material deeper than $10 \mathrm{~nm}$ (McArthur et al., 2014).

After this, the resulting dusts were analyzed in the XPS, obtaining the subsequent spectrums. It must be noticed that in the whole preparation techniques, we did not use any solvent; we used an XPS Perkin-Elmer Phi-5100 with a non-monochromatic magnesium anode and an emission of $\mathrm{K} \alpha$ of $254 \mathrm{KeV}$. This preparation and other technical details are a accord to other methodologies that have used to find pollutants in other surface analysis such particulated material from air samples (Atzei et al., 2014 and Guascito et al., 2015).

\section{Results}

As a first result we collect six fish species and choosed one to perform the XPS analysis by dehidrating and incinerating. We can observe that dehydrated samples remain wet, so we had to use a vacuum chamber, and this delayed he XPS analysis. Once the samples were completely dry, the XPS showed different spectra (Figs. 1a, $1 b$, $2 a$, and $2 b$ ) for dehydrated and incinerated samples. Results show that there is a difference in the element composition in samples from the same place. We also detected that incinerated samples have a more intense spectra. There were elements that both techniques revealed, such as oxygen, carbon, phosphorus, sodium and calcium that are characteristic of organic materials. From all elements measured, dehydrated samples analysis did not show three elements that were present: chlorine, zinc and potassium, while in the incinerated samples there are no inconsistencies (Table 2).

Table 2. XPS elemental analysis results

\begin{tabular}{cccc}
\hline $\begin{array}{c}\text { Elements } \\
\text { registered }\end{array}$ & $\begin{array}{c}\text { Energy level } \\
(\mathbf{e V})\end{array}$ & $\begin{array}{c}\text { Incinerated } \\
\text { samples }\end{array}$ & $\begin{array}{c}\text { Dehydrated } \\
\text { samples }\end{array}$ \\
\hline $\mathbf{A l}$ & 72.95 & $\mathrm{X}$ & $\mathrm{X}$ \\
$\mathbf{C l}$ & 202 & $\mathrm{X}$ & \\
$\mathbf{F e}$ & 706.8 & $\mathrm{X}$ & $\mathrm{X}$ \\
$\mathbf{N a}$ & 1070.8 & $\mathrm{X}$ & $\mathrm{X}$ \\
$\mathbf{P}$ & 136 & $\mathrm{X}$ & $\mathrm{X}$ \\
$\mathbf{S}$ & 163.6 & $\mathrm{X}$ & $\mathrm{X}$ \\
$\mathbf{S i}$ & 99.82 & $\mathrm{X}$ & $\mathrm{X}$ \\
$\mathbf{Z n}$ & 1021.8 & $\mathrm{X}$ & \\
$\mathbf{O}$ & 543.1 & $\mathrm{X}$ & $\mathrm{X}$ \\
$\mathbf{N}$ & 409.9 & $\mathrm{X}$ & $\mathrm{X}$ \\
$\mathbf{C a}$ & 346.2 & $\mathrm{X}$ & $\mathrm{X}$ \\
$\mathbf{C}$ & 284.2 & $\mathrm{X}$ & $\mathrm{X}$ \\
$\mathbf{K}$ & 294.6 & $\mathrm{X}$ & \\
\hline
\end{tabular}

On the other hand, the spectra intensities are different for incinerated and dehydrated samples, being more intense for the incinerated. This could be related with the oxygen levels result of the oxidation of the elements by heating (Hussein, 2007). We assume 
that this oxidation could maximize the elements's pikes that are missing in the dehydrated samples, and that is the reason they appear only in the incinerated analysis.


Figure 1a. XPS spectra for incinerated samples ( $A$ is the most upper sample and $F$ the lowest sample)

There are elements that are indispensable for life, these elements are hydrogen (that cannot be measured in XPS), carbon, nitrogen and oxygen (Vander Zanden and Rasmussen, 1999). There are also about 20 other that are necessary for biological processes, these are called macro and micro nutrients: calcium, phosphorus, cobalt, iron, manganese, chromium, magnesium, chloride, vanadium, iodine, sulfur, nickel, cupper, molybdenum, sodium, tin, fluorine, silicon, potassium, selenium, and zinc (Underwood, 1971). Some of these nutrients, when they are in excess, are metabolized and excreted, but some of them can be bioaccumulated and may cause illnesses. Such elements are 
cupper, cadmium, fluoride, selenium, molybdenum, vanadium and other considered severe contaminants, like lead, mercury and arsenic which may occasion dead. In the incinerated samples chloride, zinc and potassium have been detected (Tacon et al., 1984).
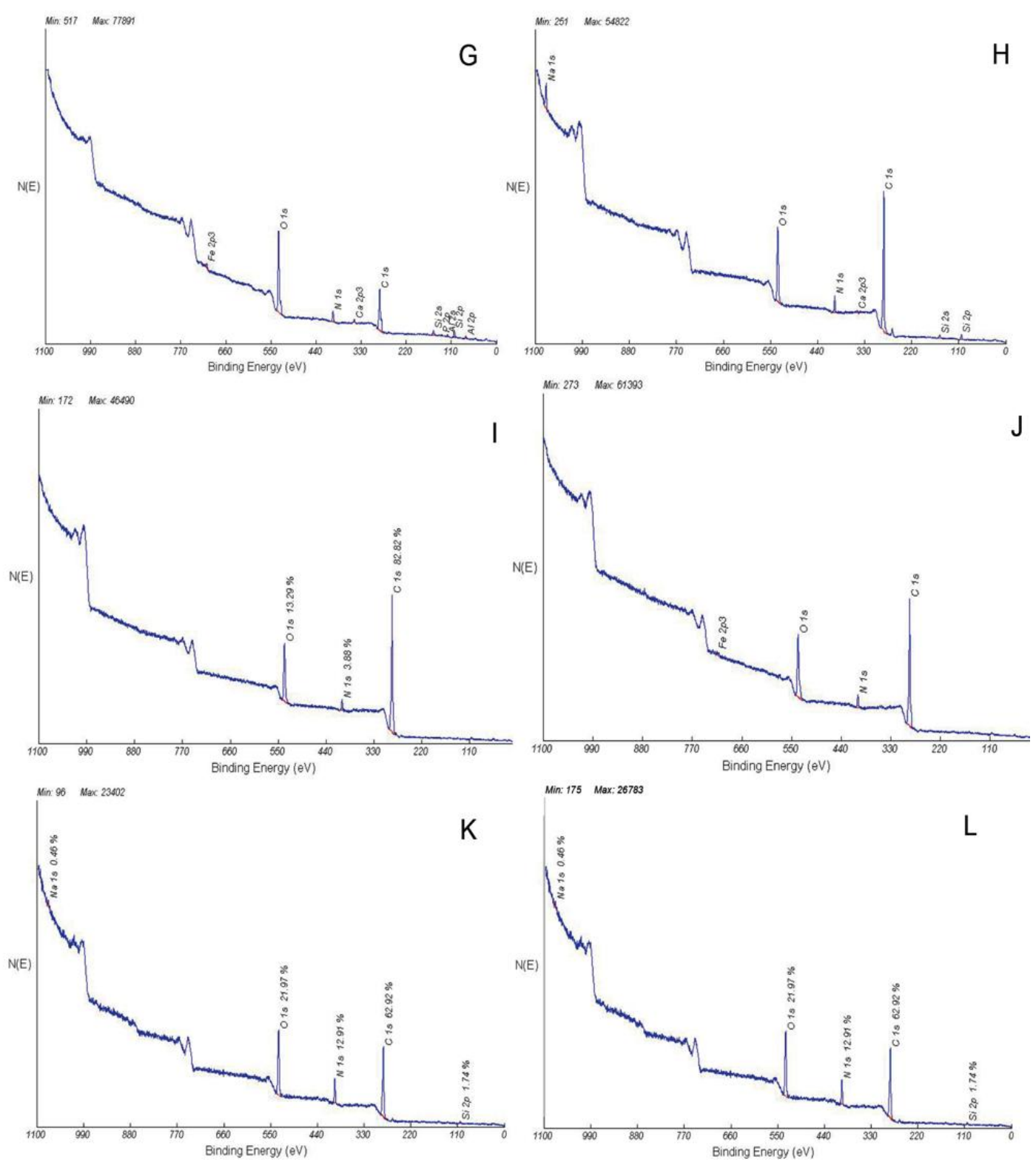

Figure $1 b$. XPS spectra for incinerated samples ( $G$ is the most upper sample and $L$ the lowest sample)

Analysis of incinerated samples shown presence of chloride, zinc and potassium, even when these elements do not represent contamination per se, is questionable that they couldn't be detected in the dehydrated samples because there must be present in organic material from living beings (Reinhold, 1975). 

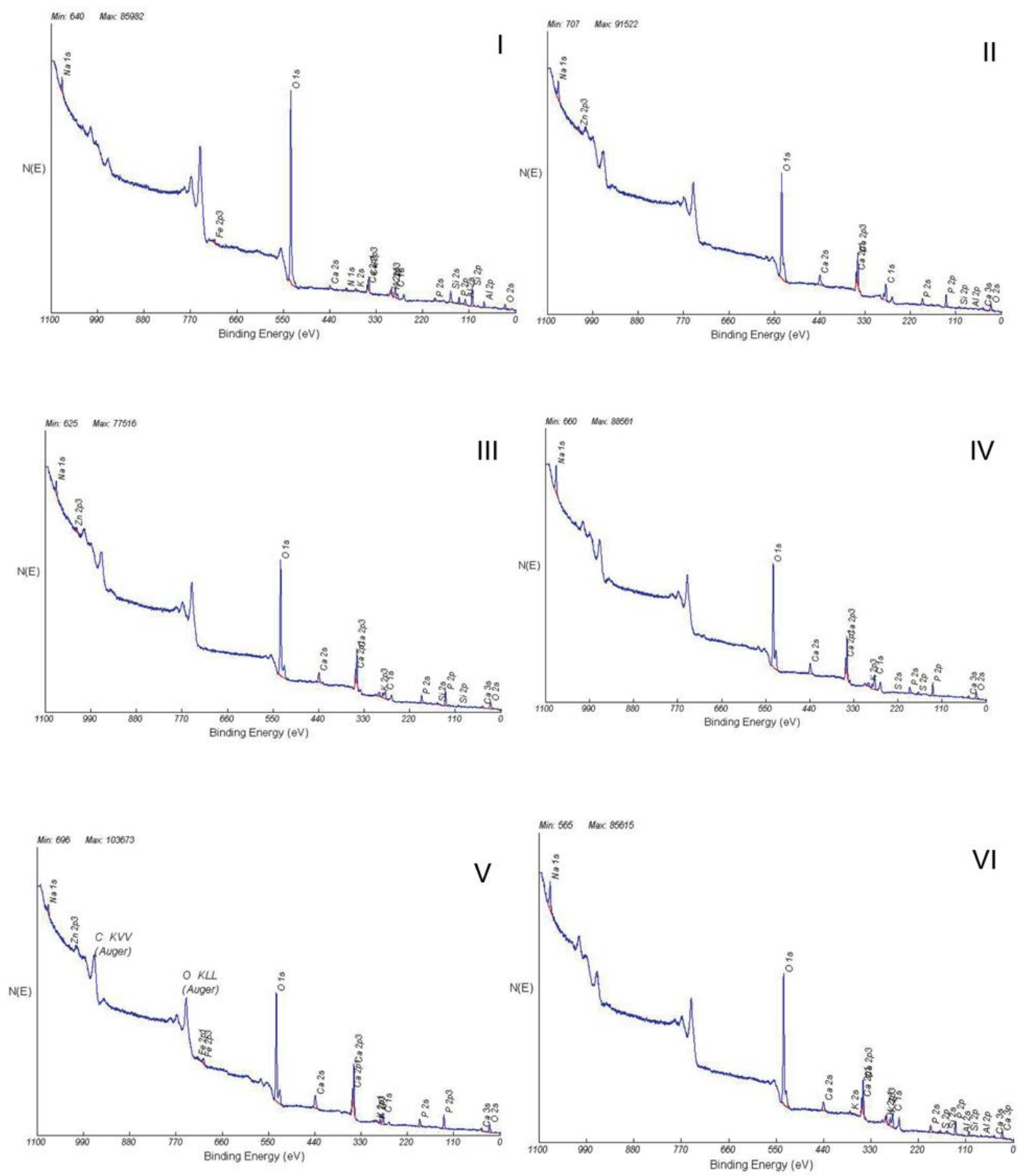

Figure 2a. XPS spectra for dehydrated samples (I is the most upper sample and VI the lowest sample)

We have already mentioned that, even there is no clear evidence of pollution just considering the XPS results; it is missing the concentration value of each element characterized because this could evidence some environmental troubles in the region (Phiri et al., 2005). For example, the cyanide used in the gold extraction process is formed with sodium $(\mathrm{Na})$, so a great amount of $\mathrm{Na}$ could indicate pollution by sodium cyanide (Chouinard and Veiga, 2008). To confirm this it is needed water quality analysis searching for each element (that could indicate environmental troubles) found in the organic materials (Charles et al., 2013). 

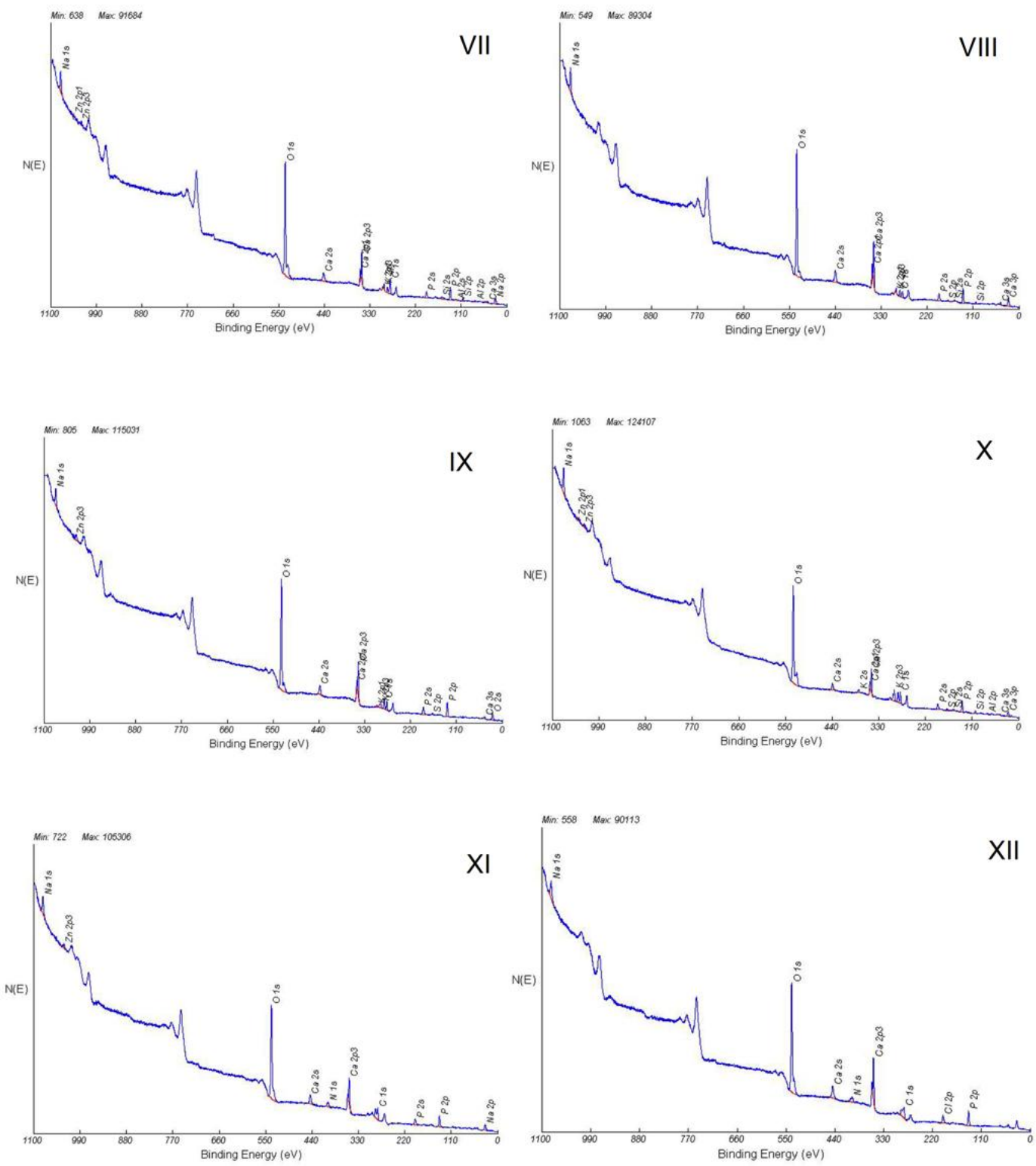

Figure 2b. XPS spectra for dehydrated samples (VII is the most upper sample and XII the lowest sample).

In conclusion, both procedures showed different results, which could not confirm water pollution at this time, but we can conclude that sample incineration must be the right technique to analyze organic materials by XPS because the high intensity of its spectra that may maximize the signal of the elements with low content. This is important to detect bioaccumulated elements that represent less the $1 \%$, which is the ideal concentration to appear in the XPS analysis without previous treatment.

Acknowledgements. Authors thanks Roberto Mora for the XPS analysis procedure at Universidad de Sonora, to Josefina Terán Linares for field trips guiding, Guadalupe Chavez Hidalgo for her helpfulness in the fish collection, and M. Alejandro Vázquez Quijada at Universidad Estatal de Sonora for helping in the samples preparation. 


\section{REFERENCES}

[1] Atzei, D., Fantauzzi, M., Rossi, A., Fermo, P., Piazzalunga, A., Valli, G., Vecchi, R. (2014): Surface chemical characterization of PM10samples by XPS. - Applied Surface Science 307: 120-128.

[2] Bundle, C. R. (1992): X-ray photoelectron spectroscopy. - In: Bundle, C.R., Evans, C. A., Wilson, S. (Eds.) Encyclopedia of materials characterization. ButterworthHeinemann, London.

[3] Carvalho, M. L., Santiago, S., Nunes, M.L. (2005): Assessment of the essential element and heavy metal content of edible fish muscle. - Anal Bioanal Chem 382: 426-432.

[4] Charles E., Thomas, D., Dewey, D., Davey, M., Ngallaba, S.E., Konje, E. (2013): A cross-sectional survey on knowledge and perceptions of health risks associated with arsenic and mercury contamination from artisanal gold mining in Tanzania. - BMC Public Health 13: 74.

[5] Chouinard, R., Veiga, M.M. (2008): Results of the Awareness Campaign and Technology Demonstration for Artisanal Gold Miners: Summary Report. - Removal of Barriers to the Introduction of Cleaner Artisanal Gold Mining Technologies. University of British Columbia, Norman B. Keevil Institute of Mining Engineering.

[6] Escalera-Vazquez, L.H., Zambrano, L. (2010): The effect of seasonal variation in abiotic factors on fish community structure in temporary and permanent pools in a tropical wetland. - Fresh Water Biology 55(12), 2557-2569.

[7] Guascito, M.R., Cesari, D., Chirizzi, D., Genga, A., Contini, D. (2015): XPS surface chemical characterization of atmospheric particles of different sizes. - Atmospheric Environment 116: 146-154.

[8] Han, J. S., Weber J.H. (1988): Speciation of methyl-and butyltin compounds and inorganic tin in oysters by hydride generation atomic absorption spectrometry. Analytical chemistry 60(4): 316-319.

[9] Hussein E. M. A. (2007): Radiation mechanics: Principles and practice. - Elsevier Science Ed.

[10] Maurice-Bourgoin, L., Quiroga I., Chincheros J., Courau P. (2000): Mercury distribution in waters and fishes of the upper Madeira rivers and mercury exposure in riparian Amazonian populations. - Science of the Total Environment 260(1): 73-86.

[11] McArthur, S. L. (2006): Applications of XPS in bioengineering. - Surface and interface analysis 38(11): 1380-1385.

[12] McArthur, S.L., Mishra G., Easton C. D. (2014): Applications of XPS in Biologyand Biointerface Analysis. - In: V.S. Smentkowski (ed.) Surface Analysis and Techniques in Biology, Springer International Publishing.

[13] Mugica, V., Amador, M.A., Torres, M., Figueroa, J.J. (2003): Mercurio y metales tóxicos en cenizas provenientes de procesos de combustión e incineración. - Revista Internacional de Contaminación Ambiental 19(2): 93-100.

[14] NOM-001-ECOL. 1996. Que establece los límites máximos permisibles de contaminantes en las descargas de aguas residuales en aguas y bienes nacionales.

[15] Oost, R., Beyer, J., Vermeulen, N.P.E. (2003): Fish bioaccumulation and biomarkers in environmental risk assessment: a review. - Environmental Toxicology and Pharmacology 13.

[16] Phiri, O., Mumba P., Moyo B.H.Z., Kadewa W. (2005): Assessment of the impact of industrial effluents on water quality of receiving rivers in urban areas of Malawi. International Journal of Environmental Science \& Technology 2(3): 237-244.

[17] Reinhold, J.C. (1975): Trace elements - a selective survey. - Clin.Chem. 21: 476-500.

[18] Rouxhet, P. G., Genet, M.J. (1991): Chemical composition of the microbal cell surface by X-ray photoelectron spectroscopy. - In: Mozes, N., Handley, P.S., Busscher, H.J., Rouxhet, P.G. (Eds.) Microbial Cell Surface Analysis: Structural and Physicochemical Methods, VCH, New York. 
[19] Tacon, A.G.J., Knox D., Cowey C.B. (1984): Effects of different dietary levels of saltmixtures on growth and body composition in carp. - Bull.Jap.Soc.Sci. Fish. 50:83-88.

[20] Taylor, H. L. D. (2008): La riqueza escondida en el desierto: La búsqueda de metales preciosos en el Noroeste de Sonora durante los siglos XVIII y XIX. - Región y Sociedad 20(42).

[21] Underwood, E. J. (1971): Trace elements in human animal nutrition. - Third edition. Academic Press, New York.

[22] Vander Zanden, M.J. Rasmussen, J.B. (1999): Primary consumer C and N and the trophic position of aquatic organisms. - Ecology 80(4): 1395-1404.

[23] Walpole, B., Merson-Davies, A., Dann, L. (2011): Biology for the IB Diploma. Cambridge University Press, UK. 